\title{
水島地区の水質污濁，特に異臭魚の発生に関する石研究
}

\author{
第 1 報 \\ 異臭魚の分布状況について \\ 岡山大学医学部公祭衛生学教室 (指導: 緒方正名教授) \\ 三 宅 与 志 雄 \\ 〔昭和44年 4 月 16 日受稿] \\ の一途をたどり，現在ではこの附近で魚萑される魚 \\ 類は，異臭のために，市場価值が低落した。 \\ 異臭魚の着臭経路, 分布等の研究は，現在まで三

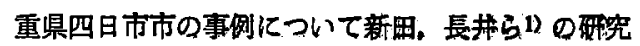 \\ があるのみである. \\ 私は水島港の公害の水質污濁に拉いて，特に異奥 \\ 魚の発生機構とその人体への毒性の研究の一璒とし \\ て，まず異臭魚の分布について測定を行なつた．そ \\ の成績をここに発表する。
}

\section{楮 雪}

岡览県倉敷市水島工業地帯が石油コンビナートを 主とするるのてある特性から，その排水である油分 による水質污濁が主要視され，そのうちです翼臭魚 の発生が問題となつている.

水島における異臭魚の問題は, 1963年高梁川河口 附近のアサリの異臭に端を発し，1965年頃加ら魚類 の異莫が問題となりはじめた。その後異臭魚は増大

第 1 図水島工業地帯に打ける異臭魚の分布状況と石神関連工場の見取図

Fig. 1 The distribution of abnormal odor fishes in Mizusima industrial area.

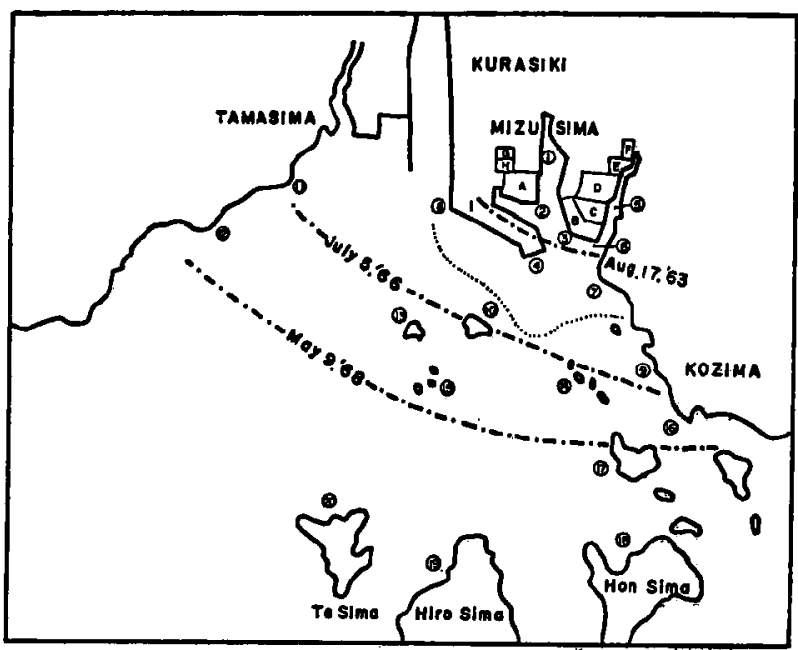

魚類探捕点

ー・ー・ー 異莫度50\%以上陽性の魚が探捕された点を結んだ編

…........ 海水の臭気度 1 の点を結んだ線

A : s 石油精製工場 B：N鉱業 C : A ダ $\quad \mathrm{D}:$ 化成M

E：M舍成 F：K軋化 H：M石油化学 G：Nカタ化学 I：K紫鉄

S Sampling stations

-.- The chain lines represents the line tied points at which more than 50 8 positive abnormal ador fishes were cought.

The dotted line represents the line tied points at which the threshold odor number of sea water was grade 1. 
$\sin \therefore \mathrm{i}$

法测

1）異臭魚の分布調査

第 1 図に示すごとく, 水島港, 呼松港及び沖合に 20 個の定点を設け, 小型底史網, 刺網及び壶網で魚 類を採捕した. 試料は実験室に搬入し，大きい魯は 3 枚におろし，小さい魚は内臟を除去し，2\%食塩 水で煮沸した後試食に供した，試食は10〜15人で行 ない，異臭を感じた魚は 1 ，異臭のないものは 0 ， 疑がわしいものは 0.5 として集計し, 試食者数で除 して百分率を算出した。 この百分率を異臭度とし， 50\%以上陽性の魚を一応異臭魚とした。

なお, 1963年の成績については, 内海区水産研究 所 (現南西海区水産研究所)の成續を用いた。

2) 【場廃水及び氷域の油分の測定 水島地区の石油関連工場及び水域の油分の測定を，

JIS, K0102，18の方法2)によつて測定した.

3) 海水の臭気度の湘定

水島港内及び沖合の水域の海水の臭気度を JISK,
0102，7の方法3 によつて測定した.

\section{測 定成 績}

第 1 図は水島工業地帯の主な工場の見取図と異臭 魚の分布範囲を示したものである.

この工業地帯の石油コンビナートには，石油精製 工場やこれに関速した石油化学工場があり，多量の 廃水を放出している。

これらの工場の廃水中の油分量の測定值は, 5 $100 \mathrm{ppm}$ であつた.

また, 水域の油分量は平均值として, 呼松水路で $0.7 \mathrm{ppm}$, 水島港内で $1.0 \mathrm{ppm}$ であつた.

異臭魚は, 油分量 $0.01 \mathrm{ppm}$ で発生するという報 告4)があり，その点加ら考察すると水島水域に生息 する魚類のうちで, 異臭魚加発灶するのも当然の事 と考えら机る。门○,

異臭度 $50 \%$ 以上の魚がこれた地点は第 1 図に併せ 示されている.

第 உ図は，第1図に示した各地点におけて採捕さ

第 2 図 年次別, 地点別, 魚種别異臭度

Fig. 2 The degree of abnormal odor by year, sampling station and fish species.

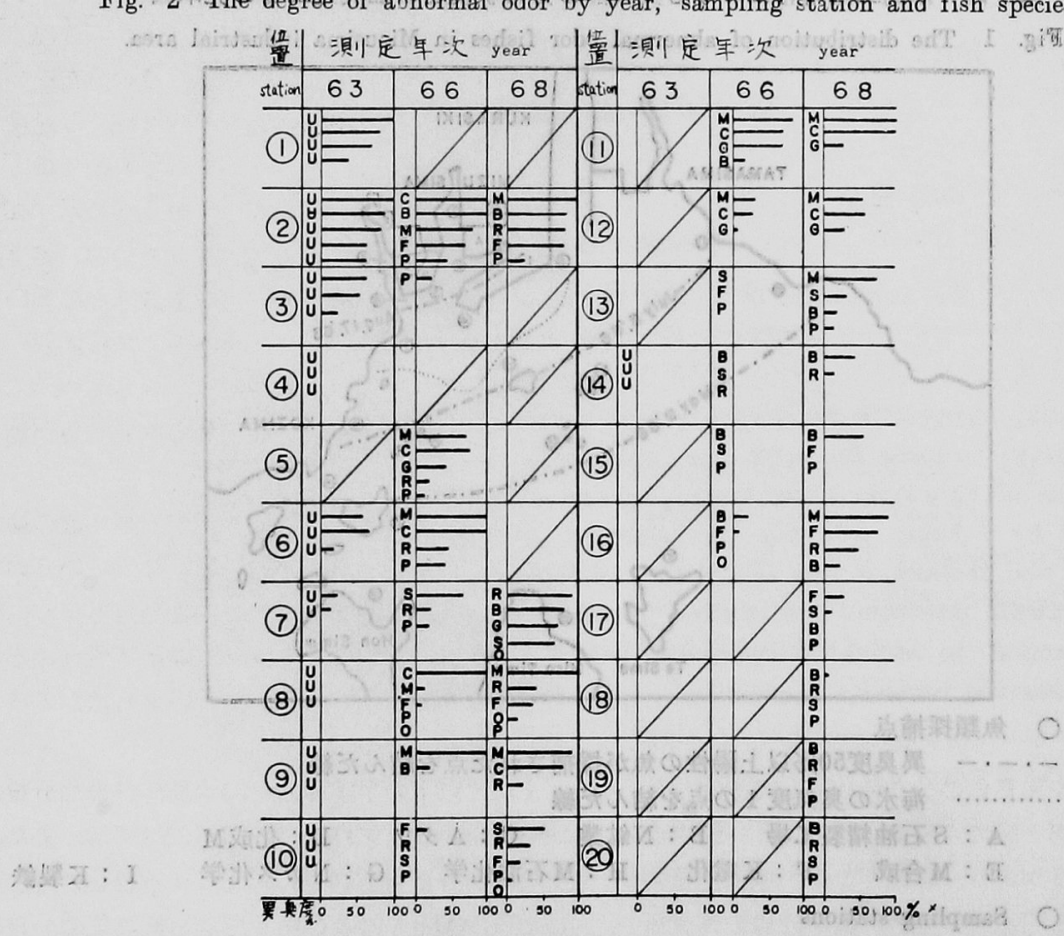

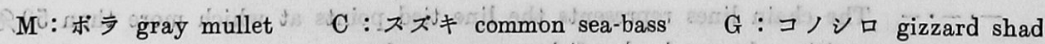
B : クロタイ black sea-bream $\mathbf{R}$ : メバル rook fish $\mathrm{S}:$ ウタタナゴ surf-fish

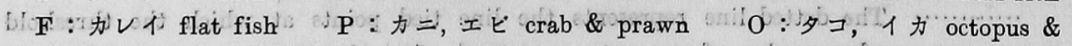
cuttle fish $\mathrm{U}$ : 魚種不明 unknown fish “ ※ The degree of abnormal odor. 
第 3 図 異臭魚の異臭度と港口からの距離

Fig. 3 Relation between the degree of abnormal odor and the distance from the month of the harbor.

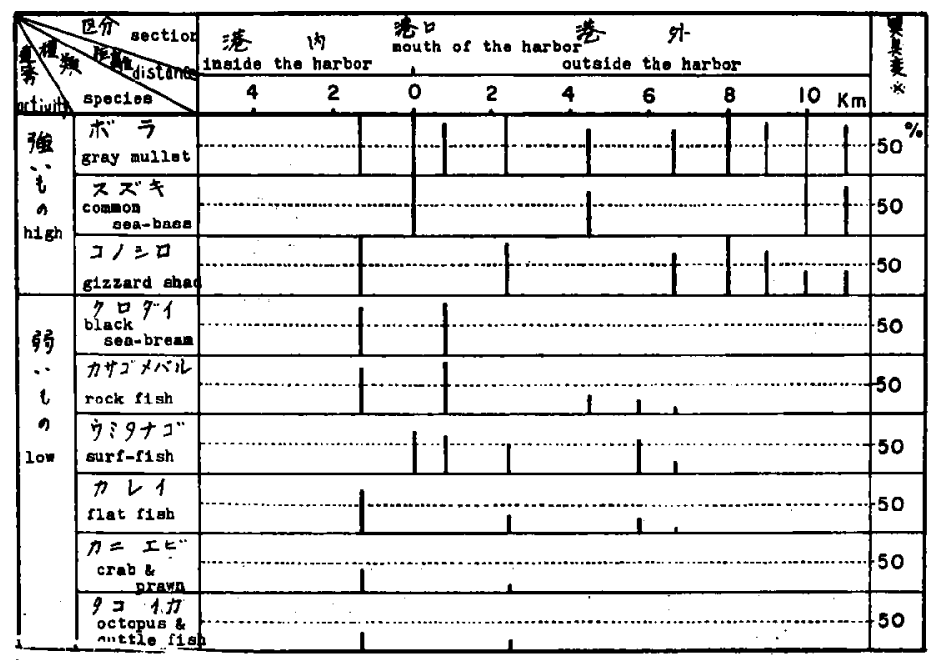

※ The degree of abnormal odor.

れた魚類の異奥度を, 年次別, 地点別魚類別に示し たあのである。

第 1 图，第 2 図の成積より，各地点において，測 定年数を增すに従つて異臭魚の増加していることが 明らかである。

また，同一地点で採捕された魚でも，遊泳力の強 いボラ, スズキ、コノシロなどの魚が遊泳力の弱い クロダイ，メバル，ウミタナゴなどの魚類よりも異 臭度が高いととが認められる。

ての点を更に明らがするため，魚の種類及びそ の異臭度と水島港口加らの距離の関係を示したもの を第 3 図に示す。

即ち，遊泳力の強いボラ，スズキ、コノシロなど は，遊泳力の弱いクロダイ、メバル，ウミタナゴな どに比して異臭魚の生息分布の広いことが明ら加に なつた、ボラ、スズキ、コノシロなどは、港口より $10 \mathrm{~km}$ 以上の点においても，異臭度50\%以上のもの が採捕されるのに反して，クロダイでは $2 \mathrm{~km}$ ウミ タナゴで $1 \mathrm{~kg}$ までが異卓魚の範囲となつている.

海水の县気度を異臭魚の分布に関連して測定した 結果を，前述の第1図に点線で示している．図中点 線内の海水は異臭があり，魚類がこの水域に生息す ると異臭魚之なる可能性が強い，四中鎖線の異臭魚 の分布範囲之比較して, 異臭海水の範囲が狭いのは, この異臭のある水域で異臭魚となつた魚類か，との 水域より外人離散するためと考えられる.

\section{総括並びに考察}

今回の成績は，石油コンビナートからの廃水中の 油分に原因する異臭魚の発生と，その分布を測定し たすのであり, 異臭魚は每年 $1 \sim 2 \mathrm{~km}$ の速度でそ の分布範囲が増大している事を示するのである.

魚種別異臭魚の分布範囲は，第 3 図化示す如く， 周边地区に見出されるのは，遊泳力の強いボラ，ス ズキ、コノシロのみである，一方遊泳力の弱いクロ ダイ、メバル,ウミタナゴその他の魚種においては， 異臭着臭水域と思われる港内及び港外については， 港口からわずかの距離の範囲にのみ異臭魚が認めら れる。

これは，冬期水島港内の水温が，高水温の廃水の ため, 沖合水温より $1 \sim 5^{\circ} \mathrm{C}$ 高くなつているので魚 類がよく港内化集まる，そして異臭魚となり，春期 水温の上昇にともなつて港外へ離散するためと考え られる. このととは，4〜6月に異臭魚が多いとと 加らあ証明できる。

また，以下の事実即ち (1)水島港内の油分量吕， 1963年を 1.0 とすれば, 1968年には17.0，また，底 土中の油分量すをれぞれ1.0，7.5 と著しい増加を示 した事，(2)第1図及び第 2 図加ら異臭魚の分布笔团 加年年増大しており，各地点におりる異臭魚の増加 と一致している事，との(1)の事実を度学的に考察 してむ，また異臭魚の発生が油分汇起因することは 
明らかであると考える.

この水島港を中心として発生する哄臭魚の分布を， 四日市のそれりと比峧すると，水蜞港で，南方へ $8 \mathrm{~km}$ ，西方へ $12 \mathrm{~km}$ の符囲であり，四日市では，北 方へ $4 \mathrm{~km}$, 北東方へ $1 \mathrm{kkm}$, 南東方へ $7 \mathrm{~km}$, 南亦 へ $7 \mathrm{~km}$ の範围であり，その分布籍囲や形状はよく 似ていることは明らかである。

\section{結 論}

水島水域を中心とした石油コンビナートからの油 分を含有する廃水とそれによつて発生する異臭魚の 分布状況を測定し, 以下の成績を得た。

1. 異臭魚の分布

水島水域の異臭魚は石油コンビナートの廃水口（ 油分 $5 \sim 100 \mathrm{ppm}$ ) の集合している水島港（油分0.7 $\sim 1.0 \mathrm{ppm}$ ）を中心として発生しており，且つその 分布範围は，毎年 $1 \sim 2 \mathrm{~km}$ の速度で増加している ことが明らかになった. そして水島港を中心として

文

1) 三重県：異臭魚飞関する特別研究報告, 1964.

2）日本規格協会：工場発水訊験方法，K 0102$1964,30 \sim 32$.

3）日本規格協会：工場廃水試䮖方法，K 0102-
南方へ $8 \mathrm{~km}$ ，西方へ $12 \mathrm{~km}$ の笎囲が異臭魚の分布 笓囲である。

\section{2. 異具魚の桠類}

異臭魚のうち，遊泳力の強いボラ，スズキ、コ

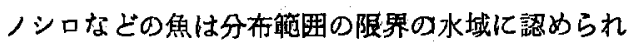
る. 一方クロダイ、メバル，ウミダナゴなどの遊泳 力の弱以魚種住，異臭の着臭する之推定される地域 のみ異臭魚が㭪媬さ机ている.

こ机は，冬期高水温の廃水のため，水温の高くな つている水島港内江魚類怔集豆り，異臭魚となって， 春期水温の上昇にともなつて虬合に離散するためと 考元られる。

稿を終えるにあたつて，ど指尊，ご校閲いただい た緒方正名教授深謝する。市た，本研究を実施す るにあたつて便宜をはかつて戴いた岡山県水産試騟 場辰星野暒氏及び岡山大学公衆衛生学教室, 枝松淑 江氏飞謝意を表する。

\section{献}

1964. $5 \sim 6$.

4）新田忠堆他：東海区水单研究所研究報告, 42, 23 36, 1965.

\title{
Studies on Abnormal Odor Fish by Oil Pollution in Mizusima Industrial Area.
}

Part 1. Distribution of Abnormal Odor Fish.

\author{
By \\ Yoshio MIYAKE \\ Department of Public Health, Okayama University Medical School \\ (Director : Prof. Masana Ogata)
}

The distribution of abnormal odor fish owing to industrial waste water from oil or its combinative industrial factories around the Miziushia waters was surveyed and the followings were obtained as the result.

1) It was found that almost all of abnormal odor fishes in the Migushima waters grow around the Mizushima harbour where many exits of industrial waste water from factaries are gathered. 
The area of the distribution is beconing more extensive with the degree of 1 or $2 \mathrm{Km}$. every year, and it has stretched $8 \mathrm{Km}$. to the south and $12 \mathrm{Km}$. to the west around the Mizushima harbour.

2) Fishes having the high swimmung activity (ex. common sea-bass, gizzard shad and gray mullet etc.) were found as abnormal odor fishes as far as the border of the distribution area, and fishes having the low activity (ex. rock, bleak sea-bream and surf-fish etc.) were found within $1 \mathrm{Km}$. from the mouth of the harbour. And the following is thinkable that fishes gather to the warm water of the Mizushima harbour owing to the high temperature of waste water of factaries and there become abnormal odor fishes, and in spring when water becomes warm, they scatter away from the harbour. 